\title{
Investigasi Pengaruh Jarak Celah Sinapsis dengan menggunakan Metode Monte Carlo
}

\author{
Eklesias Donesi Andresta, Nur Aji Wibowo, dan Adita Sutresno* \\ Program Studi Fisika, Fakultas Sains dan Matematika, Universitas Kristen Satya Wacana \\ Jl. Diponegoro 52-60, Salatiga 50711 \\ Intisari
}

\begin{abstract}
Neuron-neuron di otak manusia saling terhubung dan saling mempengaruhi satu dengan yang lain. Integrasi sinyal di otak ditentukan oleh ukuran dan kinetika respon sinapsis yang cepat. Penelitian ini bertujuan mempelajari pengaruh jarak celah sinapsis terhadap signaling melalui proses difusi dengan menggunakan program simulasi Monte Carlo Cell. Penelitian ini penting dilakukan untuk menyelidiki proses difusi dalam tubuh terkait pengaruh difusi terhadap signaling jika variabel jarak celah, luasan, dan konsentrasinya divariasi. MCell merupakan simulasi probabilistik dimana suatu solusi dari suatu masalah diberikan berdasarkan proses perhitungan probabilitas. Penelitian ini menggunakan permodelan 3 kompartemen berbentuk bola yang merepresentasikan pra-sinapsis, pasca-sinapsis, dan neuron sebagai batas luar sinapsis dan sebagai celah antara pra-sinapsis dan pasca-sinapsis. Hasil simulasi menunjukkan bahwa perubahan jarak celah memiliki pengaruh sebesar $98,86 \%$ terhadap distribusi molekul. Ukuran jarak celah yang semakin sempit menyebabkan distribusi molekul yang semakin cepat. Reseptor yang semakin luas $(6 ; 12 ; 18 ; 24)$ menyebabkan molekul yang terdistribusi meningkat $((1661 ; 2173 ; 2249 ; 2264)$ mol). Peningkatan jumlah konsentrasi $((2000 ; 4000 ; 6000 ; 8000)$ mol $)$ juga membuat laju difusi semakin cepat $((1380 ; 2806,25 ; 4203,75 ; 5565) \mathrm{mol} / \mathrm{s})$. Laju difusi yang semakin cepat menandakan bahwa proses signaling yang semakin cepat.
\end{abstract}

\begin{abstract}
Neurons in the human brain are interconnected and influence each other. Signal integration in the brain is determined by the size and the fast synapses response kinetics. This research aims to study the effect of synaptic cleft distance on signaling through a diffusion process using the Monte Carlo Cell simulation program. This research is important to investigate the diffusion process in the body related to the effect of diffusion on signaling if the cleft, area, and concentration are varied. MCell is a probabilistic simulation in which a solution to a problem is given based on the probability calculation process. This study uses modeling 3 spherical compartments representing pre-synapses, post-synapses, and neurons as the outer boundary of synapses and as a cleft between pre-synapses and post-synapses. The simulation results showed that the effect of change in the cleft distance on molecular distribution was $98,86 \%$. The narrower size of the cleft distance causes faster molecular distribution. The broader the receptor area $(6 ; 12 ; 18 ; 24)$ causes the molecules to be distributed to increase $((1661 ; 2173$; $2249 ; 2264)$ moles). An increase in the amount of concentration $((2000 ; 4000 ; 6000 ; 8000)$ moles $)$ also makes the diffusion rate faster $((1380 ; 2806.25 ; 4203.75 ; 5565)$ moles $/ \mathrm{s})$. The faster the diffusion rate indicates that the signaling process is getting faster.
\end{abstract}

Keywords: molecular distribution; signalling; synapses.

*Corresponding author: adita@staff.uksw.edu

http://dx.doi.org/10.12962/j24604682.v16i3.5095

2460-4682 @DDepartemen Fisika, FSAD-ITS

\section{PENDAHULUAN}

Pada dasarnya, segala bentuk aktivitas yang dilakukan manusia terpusat dan dikontrol oleh otak. Di dalam otak manusia setidaknya terdapat 100 miliar neuron dan setiap neuron saling terhubung serta saling mempengaruhi satu dengan yang lain [1]. Titik temu antara ujung akson neuron (prasinapsis) dengan ujung dendrit neuron lain (pasca-sinapsis) dinamakan sinapsis [1].

Ada dua jenis sinapsis yaitu sinapsis kimia dan sinapsis listrik. Sinapsis listrik adalah sinapsis yang dilalui oleh impuls arus listrik yang terdapat di antara sesama neuron. Sebaliknya, sinapsis kimia mengaktifkan sel-sel-untuk komunikasi melalui neurotransmiter yang dilepaskannya [2]. Bahan kimia ini dirilis oleh neuron pra-sinapsis menghasilkan arus sekunder di neuron pasca-sinapsis dengan mengaktifkan reseptor molekul. Jumlah neurotransmiter tidak diketahui, tetapi adalah lebih dari 100 [1,2]. Sinapsis kimia dapat dilihat pada Gambar 1.

Rilisnya neurotransmiter dipicu oleh masuknya $\mathrm{Ca}^{2+}$ melalui saluran $\mathrm{Ca}^{2+}$ yang menimbulkan peningkatan kadar 


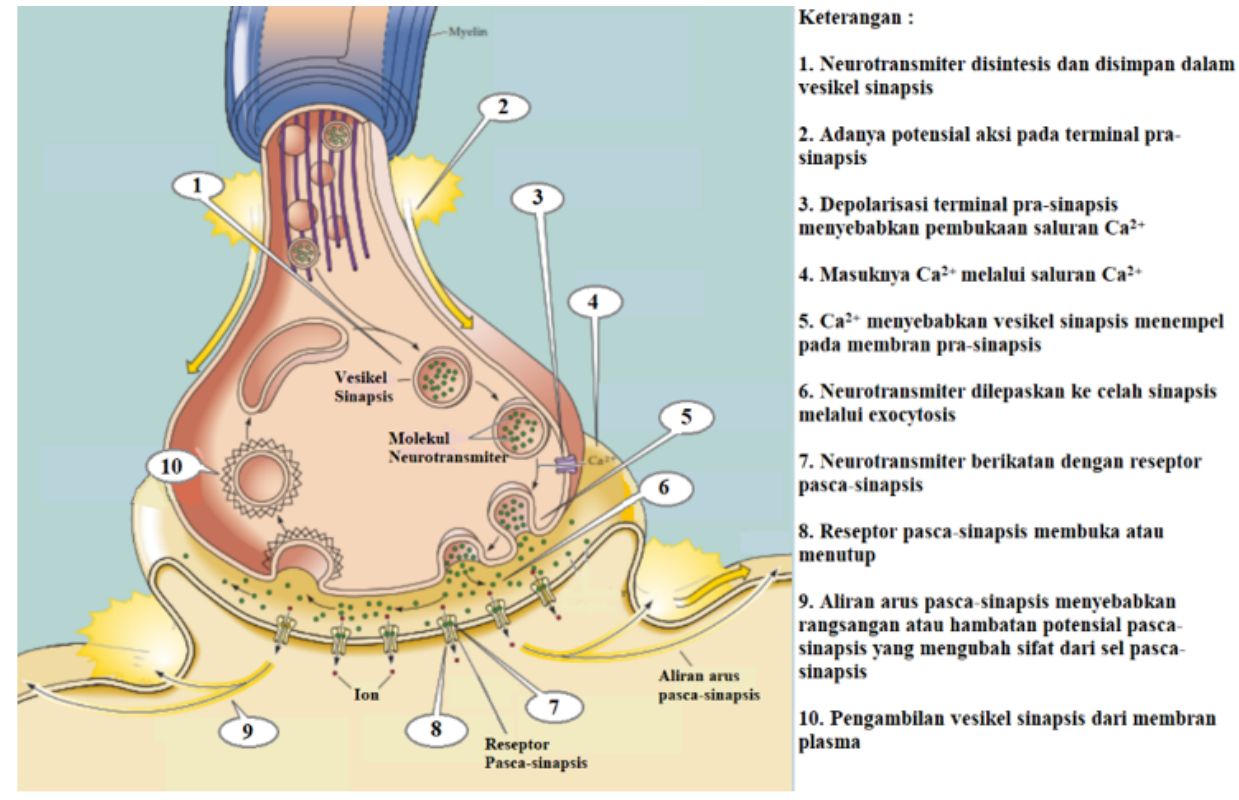

Gambar 1: Bagian-bagian pada sinapsis kimia [1] (dengan modifikasi).

$\mathrm{Ca}^{2+}$ dalam terminal pra-sinapsis $[1,3,4]$. Peningkatan kadar $\mathrm{Ca}^{2+}$ ini menyebabkan vesikel sinapsis menyatu dengan membran pra-sinapsis dan melepaskan neurotransmiter. Neurotransmiter kemudian bergerak secara acak pada celah sinapsis (cleft) untuk kemudian diterima oleh pasca-sinapsis dan terjadilah proses signaling antar neuron [1]. Peristiwa tersebut dapat terjadi dengan memanfaatkan proses difusi, dimana molekul bergerak dari konsentrasi tinggi menuju ke konsentrasi rendah $[4,5]$. Proses difusi dalam tubuh menjadi sangat penting karena proses ini mengatur pengiriman informasi antar sel, pengambilan nutrisi makanan, perkembangan embrio, dan arus pertukaran panas $[5,6]$. Secara teori, cepat lambatnya difusi dapat dipengaruhi beberapa faktor yaitu gradien konsentrasi, massa, suhu, kerapatan pelarut, luas permukaan, dan jarak tempuh $[1,7]$.

Integrasi sinyal di otak ditentukan oleh ukuran dan kinetika respon sinapsis yang cepat [8]. Celah sinapsis yang sempit dapat menyebabkan konsentrasi neurotransmiter lebih tinggi dan peningkatan aktivasi reseptor sinapsis sehingga proses signaling dari pra-sinapsis ke pasca-sinapsis akan lebih cepat [2]. Penelitian terkait cleft sebelumnya sudah pernah dilakukan oleh Leonid dan Dmitri [8]. Menurut Leonid dan Dmitri, pemodelan sinapsis diasumsikan sebagai permukaan datar menyerupai kubus dengan letak reseptor pasca-sinapsis yang digeser untuk memvariasikan jarak. Proses pengambilan data dengan menggunakan data yang diperoleh dari mikroskop elektron yang kemudian dicobakan dengan perhitungan monte carlo. Penelitian tersebut memperoleh hasil jarak celah optimal dalam proses signaling berkisar 12-20 $\mathrm{nm}$ [8].

Pada penelitian ini, pemodelan sinapsis direpresentasikan dengan pendekatan model kompartemen berbentuk bola (icosphere). Icosphere ini bentuk dasarnya adalah bola yang terdiri dari segitiga-segitiga kecil yang disebut efector tile [3]. Segitiga-segitiga ini dapat disesuaikan dengan kebutuhan dan dapat diatur menyerupai reseptor ataupun sebagai mem- bran sehingga dapat merepresentasikan model dari dinding sel sinapsis yang sesungguhnya. Perubahan jarak celah diumpamakan sebagai lintasan yang bergeser. Pergeseran dilakukan dengan menggeser pasca-sinapsis secara vertikal terhadap pra-sinapsis yang dapat dinyatakan dengan hukum Fick 1 yang berbunyi "laju difusi dalam arah $\mathrm{x}$ yang melewati suatu luasan tiap satuan waktu sebanding dengan gradien konsentrasi pada arah x" [6]. Berdasarkan hal tersebut, difusi neurotransmiter dari pra-sinapsis menuju ke pasca-sinapsis dapat dinyatakan sebagai: [9]

$$
\Theta(x, t)=D \frac{\partial C}{\partial x}
$$

dengan $\Theta$ adalah jumlah zat (mol) per luas permukaan yang dilalui zat untuk setiap detiknya $\left(\Theta=\mathrm{mol} / \mathrm{m}^{2} \mathrm{~s}\right)$.

Penelitian ini lebih menekankan pada mekanisme kerja dari proses difusi pada sinapsis, sehingga belum sampai pada bentuk permodelan sinapsis yang sesungguhnya. Penelitian ini bertujuan untuk mempelajari pengaruh signalling dari beberapa faktor diantaranya: jarak celah, luas reseptor, dan konsentrasi molekul yang terjadi pada difusi sinapsis terhadap signaling dengan menggunakan program simulasi Monte Carlo Cell (MCell). MCell merupakan simulasi probabilistik dimana suatu solusi dari suatu masalah diberikan berdasarkan proses perhitungan probabilitas dari data yang diteliti sehingga tidak memerlukan perhitungan matematis yang kompleks [10,11]. MCell adalah simulasi yang menggunakan model seluler 3-D yang realistis secara spasial dan algoritma khusus Monte Carlo yang secara spesifik digunakan untuk mensimulasikan gerakan dan reaksi molekul di dalam dan di antara sel-mikrophysiologi seluler [12]. 


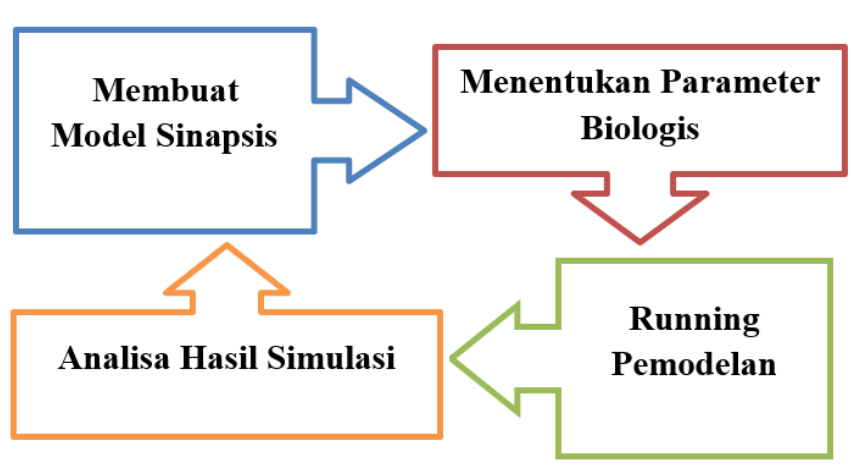

Gambar 2: Alur penelitian.

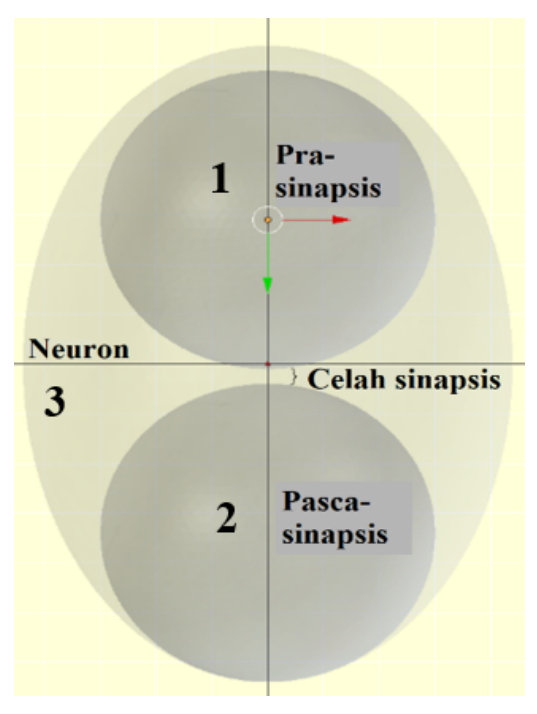

Gambar 3: Model kompartemen terdiri dari pra-sinapsis, celah sinapsis, dan pasca sinapsis.

\section{METODOLOGI}

Simulasi yang digunakan dalam penelitian ini adalah Blender 2.76b yang sudah add-on dengan Cell Blender_v1.0 dan MCell 3.3. Aplikasi ini dijalankan dengan PC (Personal Computer) dengan spesifikasi Windows 7 Intel Core ${ }^{T M}$ i76700 CPU @ 3,40 GHz GPU NVIDIA GeForce GTX 960. Adapun alur penelitian dapat dilihat pada Gambar 2.

\section{Pembuatan model sinapsis}

Model sinapsis pada penelitian ini dibuat dengan Blender 2.76b. Sinapsis direpresentasikan sebagai tiga buah kompartemen berbentuk bola (Icosphere). Ukuran sinapsis sangatlah kecil (microphysiologi) [1]. Kompartemen 1 merepresentasikan pra-sinapsis dengan luas permukaan $1,13 \mu \mathrm{m}^{2}$ dan volume $0,11 \mu \mathrm{m}^{3}$, kompartemen 2 merepresentasikan pascasinapsis dengan ukuran yang sama dengan pra-sinapsis, dan kompartemen 3 merepresentasikan celah sinapsis (cleft) dan juga sebagai neuron yang menjadi batas luar sinapsis dengan luas permukaan $3,37 \mu \mathrm{m}^{2}$ dan volume $0,57 \mu \mathrm{m}^{3}$. Penentuan luasan dan volume yang digunakan hanya hasil representatif

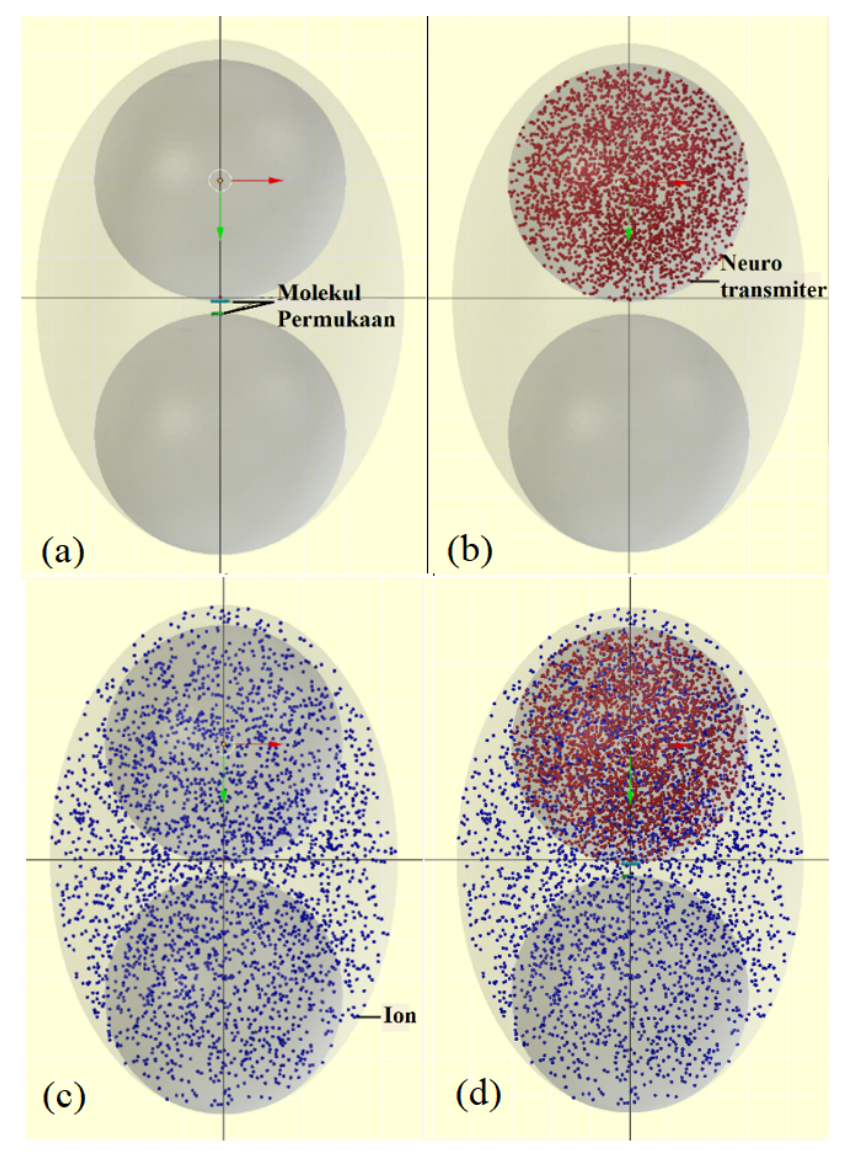

Gambar 4: Proses pemberian parameter biologis, (a) pemberian sifat dinding sel, (b) pemberian sejumlah vesikel sinapsis (neurotransmiter) pada pra-sinapsis, (c) pemberian sejumlah ion pada neuron, (d) gabungan dari sifat-sifat yang kemudian siap untuk di running.

dari sinapsis dan bukan menggunakan ukuran yang sesungguhnya. Adapun model kompartemen dalam penelitian ini dapat dilihat pada Gambar 3.

\section{Penentuan parameter biologis}

Model sinapsis yang sudah dibuat, kemudian diberikan parameter biologis menggunakan Cell Blender_v1.0 yang sudah di add-on pada aplikasi Blender $2.76 b$ sebelumnya. Pemberian parameter biologis dilakukan untuk memberi sifat pada kompartemen agar proses difusi dapat berlangsung. Proses pemberian sifat pada kompartemen dapat dilihat pada Gambar 4. Pemberian sifat dilakukan pada saat time-step $=0$ yang menandakan bahwa belum terjadi proses difusi.

Model sinapsis mula-mula yang terdiri dari neuron, prasinapsis, celah sinapsis, dan pasca-sinapsis, selanjutnya diberikan molekul permukaan seperti yang terlihat pada Gambar 4(a). Dinding pada bagian bawah dari pra-sinapsis dan bagian atas pasca-sinapsis diberikan parameter agar bersifat permeabel yang berfungsi sebagai reseptor (pintu keluarmasuknya neurotransmiter maupun ion). Terdiri dari kumpulan efector tile yang kemudian disebut lubang (efector sheet). Jumlah efector sheet yang diberikan yaitu 6, 12, 18, dan 24 
TABEL I: Nilai-nilai standar parameter biologis simulasi $[3,12]$.

\begin{tabular}{lc}
\hline \hline Parameter & Nilai Standar \\
\hline Iterasi & 80000 \\
Time Step & $1 \times 10^{-5} \mathrm{~s}$ \\
Forward rate & $1 \times 10^{8} \mathrm{M}^{-1} \mathrm{~s}^{-1}$ \\
Koefisien difusi volume & $1 \times 10^{-6} \mathrm{~cm}^{2} \mathrm{~s}^{-1}$ \\
Koefsien difusi permukaan & $0 \mathrm{~cm}^{2} \mathrm{~s}^{-1}$ \\
\hline
\end{tabular}

bervariasi sesuai dengan kebutuhan dalam pengambilan data. Pada efector sheet diberikan 100 molekul permukaan yang nantinya berinteraksi dengan vesikel sinapsis yang berisi neurotransmiter maupun ion. Koefisien difusi dari molekul ini dibuat $0 \mathrm{~cm}^{2} \mathrm{~s}^{-1}$ agar tidak turut berpindah pada saat proses difusi berlangsung. Pada pra-sinapsis diberikan molekul volume seperti terlihat pada Gambar 4(b). Molekul volume pada pra-sinapsis berfungsi sebagai vesikel sinapsis yang mana setiap vesikel sinapsis berisi 1 neurotransmiter [2]. Vesikel sinapsis kemudian berinteraksi dengan molekul permukaan pra-sinapsis melepaskan neurotransmiter. Neurotransmiter bergerak bebas pada celah sinapsis (cleft) menuju reseptor pasca-sinapsis. Neurotransmiter yang sampai akan menempel pada reseptor pasca-sinapsis untuk membukakan jalan bagi ion di dalam neuron. Jumlah neurotransmiter yang digunakan pada penelitian ini yaitu 2000, 4000,6000, dan 8000 molekul. Gambar 4(c) adalah ion-ion yang ada pada neuron. Ion pada neuron nantinya akan masuk ke dalam pasca-sinapsis dan terjadi proses signaling. Adapun jumlah ion yang digunakan yaitu 3000 ion. Gambar 4(d) adalah model sinapsis yang telah diberikan sifat dan sudah siap untuk di running menggunakan program simulasi Mcell 3.3.

\section{Running pemodelan}

Model kompartemen yang sudah diberikan sifat kemudian siap untuk di running menggunakan MCell 3.3 yang sebelumnya sudah di add-on pada aplikasi Blender 2.76b. Running dapat dilakukan ketika semua parameter sudah diinput. Adapun parameter dan nilai standar yang digunakan pada penelitian ini dapat dilihat pada Tabel I. Proses running dilakukan beberapa kali.

\section{Analisis hasil simulasi}

Hasil dari setiap running kemudian dianalisis. Ketika hasil running tidak sesuai (dalam hal ini molekul tidak berpindah, terdapat kebocoran pada membran, dsb.), maka perlu di cek kembali pembuatan model sinapsis dan seterusnya. Running yang berhasil kemudian dianalisis mekanisme difusinya. Dilakukan beberapa kali running untuk dibandingkan dengan hasil running sebelumnya agar didapatkan hasil yang optimal.

\section{HASIL DAN DISKUSI}

Dari simulasi yang dilakukan didapatkan grafik jumlah molekul terhadap waktu (s) dari setiap running menggunakan

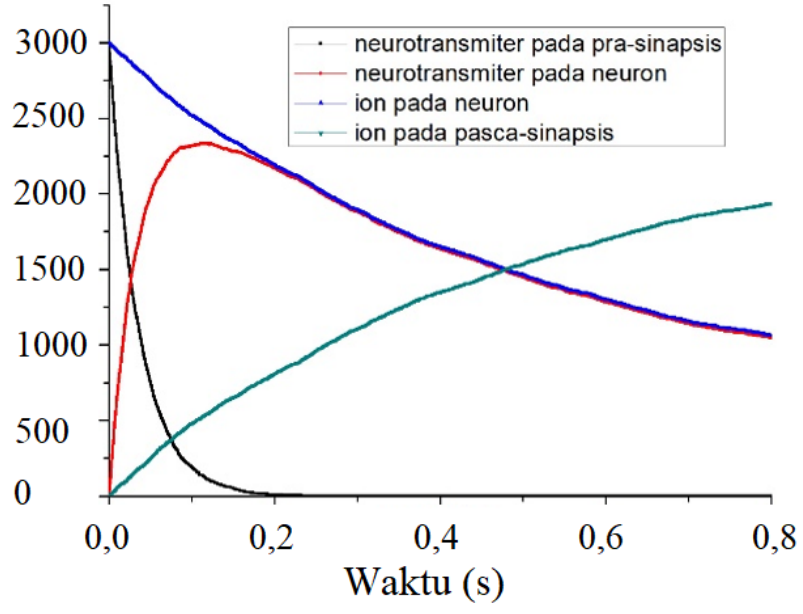

Gambar 5: Grafik hasil running menggunakan simulasi MCell (sumbu-y menyatakan jumlah molekul).

MCell seperti terlihat pada Gambar 5. Grafik tersebut merupakan salah satu hasil running dengan molekul volume pada pra-sinapsis dan pasca-sinapsis berjumlah 3000 molekul. Kerapatan molekul permukaan nilainya $1,7 \times 10^{5} \mathrm{~mol} \mu^{-1} \mathrm{~m}^{-2}$ dengan jumlah 6 lubang (element grip) berbentuk segitiga dan 100 molekul permukaan [13].

Grafik pada Gambar 5 menunjukkan bahwa distribusi neurotransmiter sebanyak 3000 molekul volume dari dalam pra-sinapsis (garis hitam dalam Gambar 5) berinteraksi dengan 100 molekul permukaan pra-sinapsis yang terdapat pada 6 lubang. Interaksi antara vesikel sinapsis dengan molekul permukaan pra-sinapsis membuat permukaan pra-sinapsis membuka dan neurotransmiter rilis dari pra-sinapsis ke celah sinapsis (cleft). Sebanyak 3000 molekul dalam pra-sinapsis terdistribusi seluruhnya dan habis setelah 0,2828 detik. Neurotransmiter yang rilis dari pra-sinapsis bergerak secara acak pada celah menuju reseptor pasca-sinapsis. Penurunan jumlah molekul di dalam pra-sinapsis diikuti dengan meningkatnya molekul neurotransmiter (garis merah dalam Gambar 5) pada neuron hingga mencapai titik tertinggi pada angka 2334 molekul. Neurotransmiter yang sampai pada reseptor pasca-sinapsis yang berjumlah 6 lubang dengan 100 molekul permukaan kemudian menempel pada reseptor pasca-sinapsis dan membukakan jalan bagi ion-ion yang berada di dalam neuron. Jumlah neurotransmiter yang semula meningkat kemudian mulai menurun dari 2334 molekul menjadi 1045 molekul di detik ke 0,8 dikarenakan neurotransmiter menempel pada reseptor pasca-sinapsis. Garis biru (dalam Gambar 5) ialah ion-ion di dalam neuron berjumlah 3000 ion bergerak menuju reseptor pasca-sinapsis yang terbuka kemudian mulai masuk ke dalam pasca-sinapsis sehingga jumlah ion dalam neuron mengalami penurunan sebanyak 1937 molekul selama selang waktu 0,8 detik secara bertahap. Penurunan ion dalam neuron diikuti dengan peningkatan jumlah ion dalam pasca-sinapsis (garis hijau dalam Gambar 5) dari 0 hingga 1937 molekul dikarenakan ion-ion yang masuk semakin bertambah. 


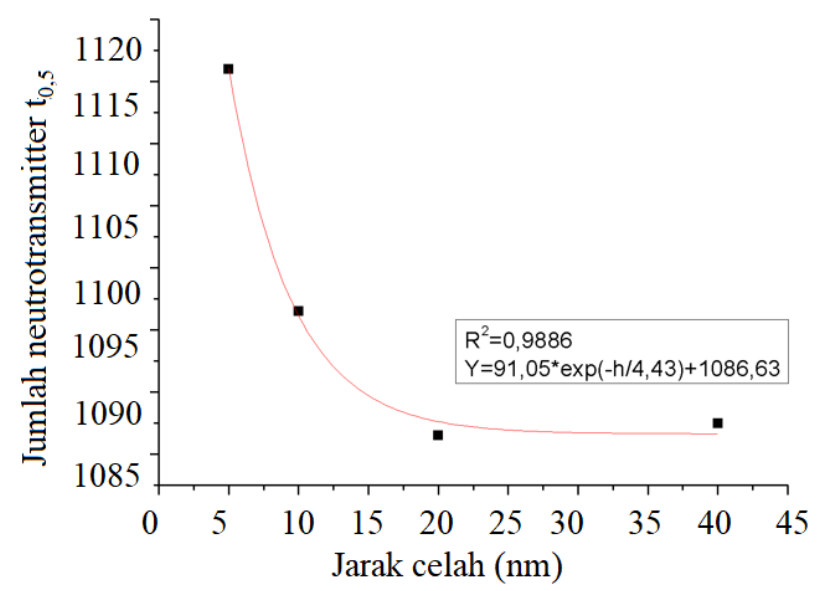

Gambar 6: Grafik jarak terhadap jumlah molekul neurotransmiter pada saat $\mathrm{t}_{0,5}$ dengan variasi jarak $5,10,20$, dan $40 \mathrm{~nm}$.

\section{Beda jarak celah (cleft) terhadap signaling}

Grafik pada Gambar 6 adalah hasil simulasi mengubah-ubah jarak celah dari 5, 10, 20, $40 \mathrm{~nm}$. Hasil simulasi menunjukkan distribusi $\mathrm{t}_{0,5}$ neurotransmiter dengan jumlah 3000 molekul volume. $\mathrm{t}_{0,5}$ adalah waktu yang dibutuhkan suatu larutan terdistribusi setengah dari jumlah konsentrasi awal menuju ke tempat lain (2). $\mathrm{t}_{0,5}$ dapat digunakan untuk memprediksi penurunan konsentrasi larutan. Pada saat jarak celah antara pra-sinapsis dan pasca-sinapsis $5 \mathrm{~nm}$, jumlah molekul yang terdistribusi 1116 molekul. Pada saat jarak celah $10 \mathrm{~nm}$, molekul yang terdistribusi 1096 molekul. Ketika jarak celah $20 \mathrm{~nm}$, molekul yang terdistribusi sejumlah 1086 molekul. Dan pada saat jarak celah $40 \mathrm{~nm}$, molekul yang terdistribusi ada 1088 molekul.

Hasil tersebut menunjukkan bahwa laju distribusi molekul berbanding terbalik dengan jarak celah. Ketika jarak celah semakin sempit, jumlah molekul yang terdistribusi setengahnya semakin banyak. Begitu sebaliknya, ketika jarak celah semakin lebar, jumlah molekul yang terdistribusi setengahnya semakin sedikit. Sehingga dapat dikatakan bahwa semakin sempit celah, semakin cepat proses signaling yang terjadi. Dari hasil curve fitting didapatkan nilai koefisien determinasi $\left(\mathrm{R}^{2}\right)$ sebesar 0,9886 dimana hasil tersebut menyatakan bahwa pengaruh jarak celah terhadap distribusi molekul sebesar 98,86\% dengan persamaan distribusi molekul $\mathrm{y}=$ $91,05 * \exp \left(-\frac{h}{4,43}\right)+1086,63$; dengan y adalah laju distribusi molekul, dan h adalah jarak celah (nm). Hasil simulasi sesuai dengan hukum Fick 1 dimana semakin sempit jarak celah, laju difusi semakin besar [9].

\section{Luasan reseptor terhadap signaling}

Pada simulasi ke-2, jumlah lubang pada pasca-sinapsis di buat bervariasi dengan variasi angka 6,12,18, dan 24 seperti terlihat pada Gambar 7. Garis hitam menunjukkan lubang 6,
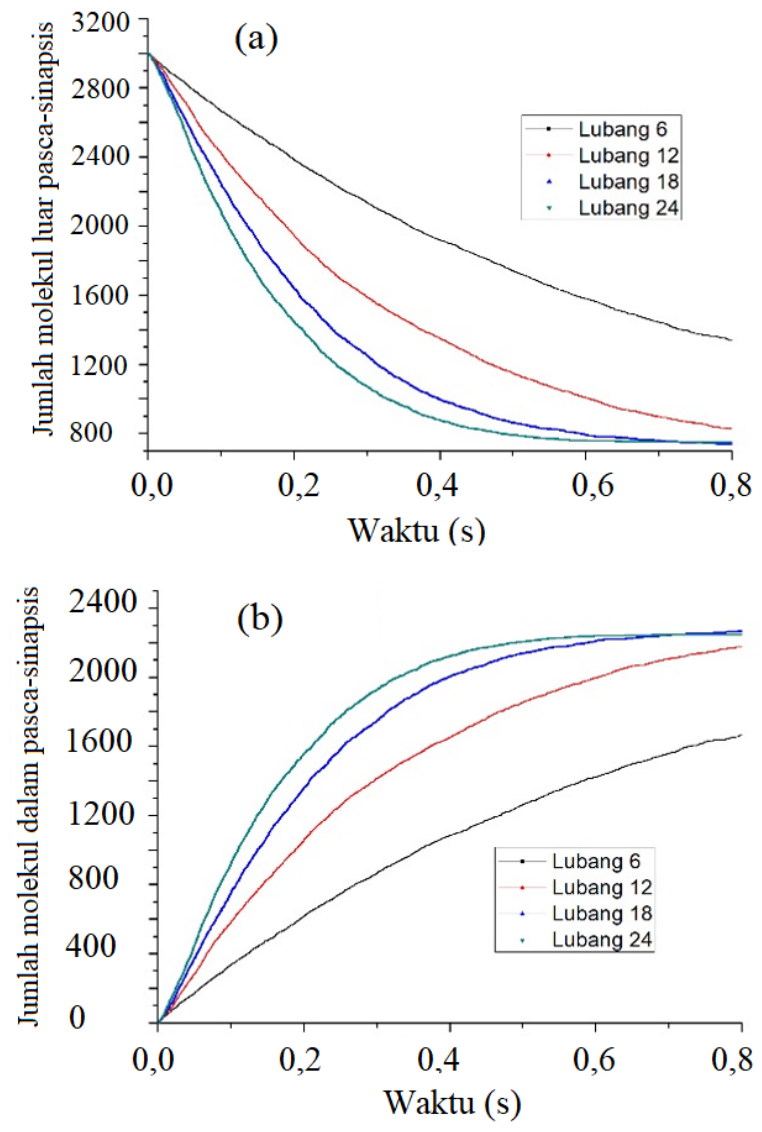

Gambar 7: Grafik hubungan jumlah molekul terhadap waktu, (a) molekul di luar pasca-sinapsis, (b) molekul di dalam pasca-sinapsis, dengan variasi lubang 6, 12, 18, dan 24 .

garis merah menunjukkan lubang 12, garis biru menunjukkan lubang 18, dan garis hijau menunjukkan lubang 24. Jumlah lubang yang berbeda menandakan jumlah luasan reseptor pada pasca-sinapsis juga berbeda. Molekul permukaan juga turut bervariasi dari 10 molekul untuk lubang 6, 20 molekul untuk lubang 12, 30 molekul untuk lubang 18, dan 40 molekul untuk lubang 24 dengan tujuan agar kerapatan dari lubang selalu sama. Jumlah molekul yang berdistribusi dibuat konstan yaitu 3000 molekul.

Hasil simulasi menunjukkan bahwa kecepatan difusi dari tiap luasan reseptor berbeda-beda. Urutan kecepatan difusi dari yang paling lama ke yang paling cepat berturutturut $6,12,18$, dan 24. Jumlah molekul yang terdistribusi berturut-turut yaitu 2264, 2249, 2173, dan 1661 dari luasan besar ke luasan sempit. Sehingga dapat dikatakan bahwa semakin luas reseptor pasca-sinapsis, menyebabkan kecepatan distribusi molekul juga semakin cepat yang artinya proses signaling yang terjadi juga akan semakin cepat. Jumlah molekul yang meninggalkan luar pasca-sinapsis (Gambar 7(a)) maupun yang masuk ke pasca-sinapsis (Gambar 7(b)) nilainya sama sehingga dapat dikatakan bahwa fungsi reseptor hanya sebagai pintu untuk keluar-masuknya molekul pada pasca-sinapsis dan ini juga menegaskan bahwa difusi mengalir dari konsentrasi tinggi ke konsentrasi rendah [13]. 


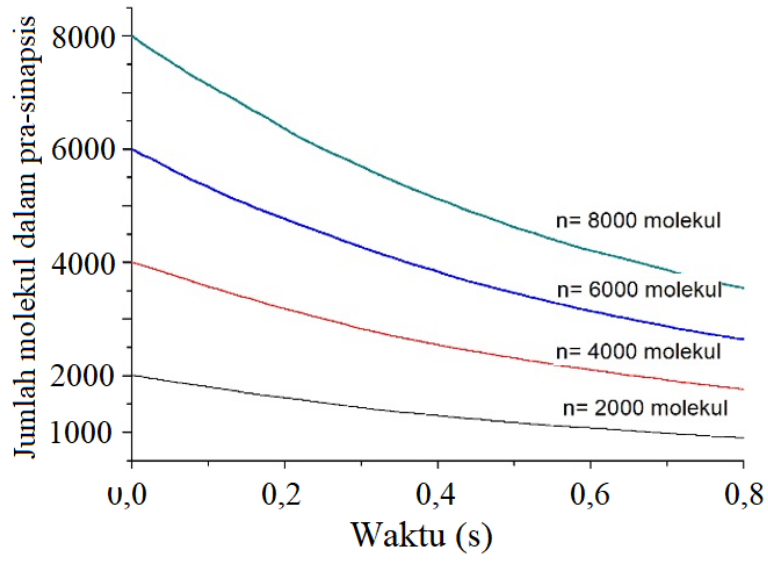

Gambar 8: Hubungan jumlah molekul terhadap waktu dengan jumlah molekul yang meningkat dari 2000 molekul (garis hitam), 4000 molekul (garis merah), 6000 molekul (garis biru), dan 8000 molekul (garis hijau). Peningkatan jumlah molekul menyatakan konsentrasi yang semakin meningkat.

\section{Konsentrasi molekul terhadap signaling}

Untuk mencari pengaruh konsentrasi molekul terhadap signaling, dilakukan simulasi dengan memvariasikan jumlah molekul $n=2000$, 4000, 6000, 8000 dengan jumlah reseptor pasca-sinapsis yang sama yaitu 6 lubang seperti pada Gam- bar 8. Data yang diperoleh menunjukkan bahwa laju difusi molekul 2000, 4000, 6000, dan 8000 berturut-turut adalah $1380 \mathrm{~mol} / \mathrm{s}, 2806,25 \mathrm{~mol} / \mathrm{s}, 4203,75 \mathrm{~mol} / \mathrm{s}$, dan $5565 \mathrm{~mol} / \mathrm{s}$. Sehingga dapat dikatakan bahwa semakin besar nilai gradient konsentrasi, maka semakin besar nilai laju difusinya seperti yang ditunjukkan pada Pers.(1) [9]. Semakin besarnya nilai laju difusi menandakan proses signaling semakin cepat.

\section{SIMPULAN}

Simulasi Monte Carlo Cell dapat digunakan untuk menyelidiki peristiwa difusi pada sinapsis. Jarak berpengaruh pada proses signaling. Semakin sempit jarak celah, signaling akan semakin cepat begitu sebaliknya. Hal ini menandakan bahwa laju distribusi molekul berbanding terbalik dengan jarak celah. Dari hasil curve fitting didapatkan nilai R2 sebesar 0,9886 yang artinya jarak celah terhadap distribusi molekul memiliki pengaruh $98,86 \%$ dengan persamaan distribusi molekul y $=91,05 * \exp \left(-\frac{h}{4,43}\right)+1086,63$. Pada simulasi luas reseptor terhadap signaling terlihat bahwa semakin luas reseptor pasca-sinapsis, semakin cepat distribusi molekulnya. Hal ini menandakan bahwa semakin sempit luasan reseptor, proses signaling juga akan semakin lambat. Hasil simulasi pengaruh jumlah konsentrasi menunjukkan bahwa jika semakin besar konsentrasinya, maka laju difusinya juga akan semakin cepat. Semakin cepat laju difusi menandakan bahwa semakin cepat proses signaling yang terjadi.
[1] D. Purves, et al., "Neuroscience", Third Edition, Sinauer Associates, USA, 2004, pp. 93-126.

[2] D. Fretche, U. Pannasch, N. Rouach, \& D. Holcman, "Synapse Geometry and Receptor Dynamics Modulate Synaptic Strength", Plos one, vol. 10, no. 6, pp. e25122, 2011.

[3] A. Sutresno, et al., "Diffusion and Interaction between ion $\mathrm{Ca} 2+$ and ion $\mathrm{Gd} 3+$ in a Model Synapse: A Monte Carlo Study", Journal of Physics, vol. 1127, pp. 1-6, 2019.

[4] A. Gil, et al., "Monte Carlo Simulation of 3-D Buffered Ca2+ Diffusion in Neuroendocrine Neurons", Biophysical Journal, vol. 78, pp. 13-33, 2000.

[5] S. Trihandaru, A. Widyayanti, S. Rachmawati, dan B.S. Toenlioe, "Pemodelan dan Pengukuran Difusi Larutan Gula dengan Lintasan Cahaya Laser", Prosiding Pertemuan Ilmiah XXVI HFI Jateng \& DIY, 2012.

[6] B. Haryanto, "Pengaruh Pemilihan Kondisi Batas, Langkah Ruang, Langkah Waktu, dan Koefisien Difusi pada Model Difusi”, Jurnal Aplika, vol. 8, 1-7, 2008

[7] Yahya, "Perbedaan Tingkat Laju Osmosis Antara Umbi Solonum Tuberosum dan Doucus Carota", Jurnal Biology Education, vol. 1, no. 4, hlm.1-2, 2018.

[8] P.S. Leonid, \& D.A. Rusakov, "The optimal height of the synap- tic cleft", PNAS, vol. 6, no. 104, pp. 1823-1828, 2007.

[9] D. Oktavia, "Solusi Asimtotik pada Persamaan Difusi dengan Waktu Singkat", Jurnal Matematika, vol. 8, hlm. 43-51, 2018

[10] H.D. Hutahean, "Analisa Simulasi Monte Carlo untuk Memprediksi Tingkat Kehadiran Mahasiswa dalam Perkuliahan", Journal Of Informatic Pelita Nusantara, vol. 1, no. 3, pp. 25413724,2018

[11] A.K. Rex, et al., "Fast Monte Carlo Simulation Methods for Biological Reaction-Diffusion Systems in Solution and on Surface", SIAM J. Sci. Comput., vol. 30, no. 6, pp. 3126-3126, 2008.

[12] A. Sutresno, et al., "Kajian Mekanisme Difusi pada Sistem Mikrophysiologi Model pada Monte Carlo Simulator Cell (MCell)", Prosiding Seminar Kontribusi Fisika, Bandung, 2014.

[13] A. Sutresno, et al., "Studi Pengaruh Luasan dan Jumlah Molekul pada Membran terhadap Distribusi Molekul pada Sinaps Menggunakan Metode Monte Carlo", Prosiding Simposium Nasional Inovasi dan Pembelajaran Sains (SNIPS, Bandung, 2016. 